\title{
Recycled Asphalt as an Alternative to Natural Aggregates for Forest Road Reinforcement
}

\author{
Petr Hrůza, Jaroslav Blahuta, Petr Pelikán, Lucie Olišarová, Jiří Nedorost, \\ Tomáš Mikita, Zdeněk Patočka
}

\begin{abstract}
The objective of the present paper is to confirm or reject the possible use of recycled asphalt to reinforce forest haul roads regarding the technical requirements set by the standards and directives relevant to the construction of forest road surfaces. The hypothesis is based on the presumption that recycled materials, if correctly used, can reach the same construction properties as standard materials, hence their application does not have a negative effect on reinforcement quality. On a selected stretch of the forest road, three test sections were constructed with the use of recycled asphalt, however, each of them with a different technological solution. The first section was reinforced with unbound mixture - Type1 without added water, the second section was constructed using a version of vibrated macadam technology, and recycled asphalt was applied to the third section by the method of basic compacting. In each of the sections, tacheometric cross profile measurement was carried out at monthly intervals to monitor the changes in the cross profile shape, and the number of passages of fully loaded logging trucks was registered; static load tests were performed at pre-defined time intervals to determine the deformation moduli such as deformation characteristics of the road surface structural layers. In all three reinforcement versions, the values of deformation moduli observed during the static load tests were between 68-90\% of the values set by relevant standards for these technologies using natural aggregates. However, the tacheometric measurements did not reveal statistically significant changes in the shape of the reinforcement cross-section. Based on the obtained results, applying recycled asphalt to reinforce forest roads seems to be a suitable alternative to natural quarry aggregate used in unbound structural layers. Recycled material needs to meet the regulatory limits for foreign elements and pass ecotoxicity tests, which is evidenced by a certificate on material compliance issued by the test laboratory.
\end{abstract}

Keywords: recycled materials, forest accessing, unsealed road surface, static load test, deformation modulus

\section{Introduction}

Humans have been looking for a suitable and effective concept for landscape accessibility for as long as we know. At first, it was due to finding new settlements, searching for food, increasing trade and exploiting mineral wealth. From the historical perspective, it is evident that the first forest roads were reinforced with natural material occurring in the construction locality (Hrůza et al. 2016), especially readily available stone and wood. With increasing mechaniza- tion, the volume of transported material and new technologies, people gradually brought new materials into the landscape. Handmade stone pitched roads were first replaced with mechanized application of natural crushed aggregates (Makovník et al. 1973) and later by sealed running surfaces (Gruber 2003). This activity resulted in approx. $46,800 \mathrm{~km}$ forest roads in the territory of the Czech Republic with the forest road network density of $18 \mathrm{~m} \cdot \mathrm{ha}^{-1}$ (MZe 2010).

After their service life, asphalt reinforced roads disintegrate and turn into a form of construction waste 
in the landscape. Nowadays, we are facing the challenge of re-using this construction waste and placing it alongside the primary raw materials. Waste recycling means repeated use of the resources that have already been used (De Beir et al. 2010). Primarily, the effort is aimed at the maximum possible saving of raw material resources, fuels and energy, reduction of waste volume and sustainable economics (Cimpan et al. 2016). Secondly, material recycling contributes to environment conservation, but also to prevent pollution (Jagannadha Rao 2015). The increasing volume of demolition works in recent years has forced society to re-use the generated demolition waste (Jagannadha 2015). Due to this, there has been a natural increase in the use of recycled material in civil engineering (Leite 2011). In road construction, recycled material is most often used in base construction layers (Wu et al. 2014).

\subsection{Use of Recycled Material for Forest Road Reinforcement}

The technological, ecological and economical aspects of recycled asphalt use in road construction are discussed in Liu et al. (2016). Garach et al. (2015) dealt with the mechanical properties of recycled materials formed with cement binders for non-reinforced active zone of the road formation. Similar to other authors (Tabsh and Abdelfatah 2009, Kang et al. 2011, Rao et al. 2011, Xuan et al. 2012), they came to the conclusion that these materials show lower density, higher absorption capacity and lower mechanical strength than natural materials. From the economical perspective, Hoppe et al. (2015) claimed that material costs can be reduced by as much as $30 \%$ when a mixture of recycled material and natural aggregates at a 50/50 ratio are used.

Schlaghamersky and Barfod (1993) and Hirt (1998) began to study the use of crashed brick, concrete, tiles and ceramics for reinforcement of forest road network in Germany. In Spain, Agrella et al. (2012) applied a mixture of recycled materials directly in road structure and, after two years, the road did not show any signs of deformation defects. Behnood et al. (2015) monitored the mechanical, physical, chemical and rheological characteristics of construction waste applied directly onto the subgrade during road construction. Behnood et al. (2015) focused on the use of copper slag as an alternative to recycled asphalt in the cold-mix technology. They mixed copper slag with limestone, recycled asphalt, Portland cement and rice husk ash. All mixtures with Portland cement showed excellent results.
Kaakkurivaara et al. (2016) discussed the topic of forest road network reinforcement with fly ash and its mixtures; in their study, a forest road was renovated using fly ash, a by-product of wood and peat combustion from Finnish bioenergy production. Other authors tested the applicability of ash in forest road network reinforcement. Edil and Benson (2007) used coal ash and Bohrn and Stampfer (2014) tested wood ash to stabilize forest road subgrades. Lahtinen (2001) reported the use of bio-ash for road formation stabilization. Vestin et al. (2012) mixed fly ash with gravel; this mixture was then laid out onto an existing forest road and worked into the active zone of the subgrade with a grader. The road was subsequently tested by the light dynamic plate test for the period of one year. Recycled (reclaimed) asphalt is frequently used for pavements, where they replace crushed aggregates together with slag (Wu et al. 2014, Saride et al. 2016). Zhang and Gao (2015) applied a modified mixture of cement and recycled rubber from tyres for pavement construction.

\subsection{Regulations Relevant to Use of Recycled Materials in Special-Purpose Roads}

The use of recycled construction and demolition waste in road formations, subgrades and construction layers of roads in the Czech Republic is regulated in the Technical Conditions (thereinafter TC) 210 (2011) Recycled aggregates may be combined with natural or artificial aggregates, however, these mixtures must meet the same requirements as the single-component mixtures, including the tested properties. These requirements are, besides other regulations, set by the standards for unbound mixtures based on standards ČSN 73 6126-1 Road building - Unbound courses Part 1: Construction and conformity assessment (2004) and ČSN 73 6126-2 Road building - Unbound courses - Part 2: Vibrated macadam course (2006).

Recycled asphalt is a homogenized mixture of aggregates and asphalt obtained by milling, demolition, crushing and sorting of road construction layers intended for further technological use in roads (Wen et al. 2013). The method of its production has a significant impact on the quality of the material used for road construction. In the territory of the Czech Republic, recycled asphalt can be used to construct forest roads provided that it has a valid certificate of origin and meets the requirements for ecological safety set by the Czech construction standard (thereinafter C SN) Forest Road Network 736108 (2016). The same applies to quarry stone used for forest road reinforcement. It is not possible to use local material in some countries such as the Czech Republic, and a valid certificate of 
origin from the quarry is needed. The price of recycled material is generally lower than that of quarry aggregate (1.3 EUR/t compared to $8.3 \mathrm{EUR} / \mathrm{t}$ in this case) so the choice of reinforcement material is made based on an economic analysis of the distance and the amount of material to be transported from its source.

Design of road construction layers using recycled materials is described by TC 170 (2004) and TC $170-$ amendment (2010). According to standard ČSN 73 6114 Road Pavements - Basic Requirements for Design (1995), using described recycled construction material is suitable in base and protective layers of $5^{\text {th }}$ and $6^{\text {th }}$ classes of traffic load and design damage level D2. This means the transport intensity of a maximum one hundred designed vehicles per day, respectively fifteen vehicles and surface damage up to a maximum of $20 \%$ of the running surface area. Minimum values of the wearing courses deformation moduli (Edef2) are set in the technical conditions of the Rural Roads Catalogue (2011) and are also relevant for forest road construction. Rural and forest roads have to meet the same regulatory maxima regarding the load bearing capacity per vehicle axle as other public roads. Forest roads are often continued field roads and in such cases they have to meet the design parameter of passage and the mentioned rural roads will be constructed in compliance with the standard for forest roads. For a subgrade deformation modulus of $30 \mathrm{MPa}$, the minimum wearing course deformation values required for the individual types of reinforcement are as follows: $115 \mathrm{MPa}$ for unbound mixture - Type $1(180 \mathrm{~mm}$ thick), $110 \mathrm{MPa}$ for vibrated macadam (200 mm thick) and $100 \mathrm{MPa}$ for basic compacting (200 mm thick).

\subsection{Benefits and Aims of Work}

Forest haul road reinforcement should be viewed as a complex issue. Forest road networks must suit the needs of timber haulage methods used in the area, respect the parameters of the logging vehicle design set by the legislation and standards, and follow the economic as well as technological aspects and environmental considerations while constructing individual road construction layers. Nowadays, forest roads are mainly reinforced with unbound mixtures of natural quarry aggregates. For other public roads, recycled material is usually recommended to construct the bottom layers of road reinforcement, but not for the running surfaces. Using recycled material is currently a life philosophy and reduces earth exploitation, especially in a forest ecosystem; additionally, when it meets the economic balance and regulatory limits, we can talk about environment-friendly management. This is how the technological versions tested within this study differ from the construction methods used so far. The described technological solution shall confirm or reject the possible use of recycled asphalt to reinforce forest roads regarding the technological requirements set by the standards relevant to constructing road surfaces. Within the testing of recycled asphalt applicability, three commonly used forest road reinforcement technologies were compared, including their behaviour in time.

\section{Material and Methods}

Due to the fact that road surface loading with traffic is a gradual and long-term process, it was necessary to monitor the state of individual reinforcement technologies over a longer period (Cibonau et al. 2012, Trcinski et al. 2013). Three test sections with different types of reinforcement were constructed for the purposes of the research, and the deformation characteristics of the road reinforcement were monitored in each section by static load test according to standard ČSN 721006 - Compaction control of engineering fills (1998), tacheometric cross profile measurements were carried out to monitor the height changes of the cross profile shape and the number of fully loaded logging truck passages during measurement period were registered. Similar international standards and regulations are e.g. DIN 18134 Baugrund; Versuche und Versuchsgerate; Plattendruckversuch (1990), BS 1377, Part 4: Soil testing methods for civil engineering purposes. Compactionrelated tests are ZTVE StB 94: Zusatzchlische Technische Vertragsbedingungen und Richtlinien für Erdarbeiten im Strassenbau.

The measurements were carried out during the vegetation seasons in 2016 (May - October) and 2017 (April - June). Tacheometric measurements and monitoring the number of passages were done at monthly intervals and the static load tests were performed every two months. In total, 9 tacheometric measurements and 5 static load tests were carried out for each of the reinforcement versions.

\subsection{Area of Study}

The Research was Carried Out on Forest Road "Babidolská" Owned by the Forest Training Enterprise »Masaryk Forest « in Křtiny, Mendel University in Brno, to the North-East of Brno (Coordinate System S-JTSK 596627, $1149535 \mathrm{~m}$ ) in the Territory of the Czech Republic. This Secondary Forest Road Is Used for Seasonal Transport of Timber and Was Constructed in Category 4.0/20 (Width of the Road Crown in $\mathrm{m}$ and the Design Speed in $\mathrm{km} / \mathrm{h}$ ) without Constructional Layers on the Subgrade; the Subgrade was Reinforced 
by Crushed Aggregate Width of $20 \mathrm{~cm}$, Mixed with Soil in the Active Zone of the Subgrade. Technological Solutions of the Test Sections

The original forest road was reinforced with aggregate fraction 32/63 in a $200 \mathrm{~mm}$ thick layer. The aggregate came from the local quarry, the type of sedimentary rock greywacke that shows high strength in compression. Therefore, it is often used for crushed aggregate, pavement blocks, and rough masonry. It mainly contains quartz and small rock fragments and, to a lesser extent, also (among others) feldspar. Within the study, coarse crushed aggregate was blended with earth due to the use of this forest road and formed the main reinforcement of the active zone of this road subgrade. Within the study, this original layer of basic compacting was removed (Fig. 1) and a new subgrade was formed with a blade grader into a crowned shape with $2 \%$ slope and compacted with a vibrating roller. The deformation modulus values of the second loading cycle (Edef2) of this new subgrade reached 50.0 MPa with the Edef2/Edef1 ratio of 1.46. This shows the deformation modulus in the first and second loading cycle of the static loading test and allows elimination of a potential material compacting effect during the first loading cycle. If the Edef2/Edef1 ratio is over 2.5, it shows that the layer has not been compacted well by the vibrating roller during construction, but was compacted during the first loading cycle of the static test.

All recycled material was prepared by cold recycling. At a selected part of the forest road, three different types of construction layer were constructed as surfacing on the subgrade. The first section was reinforced with unbound mixture-Type1 technology with a mixture of recycled material fraction $0 / 80$ (mix of frac-

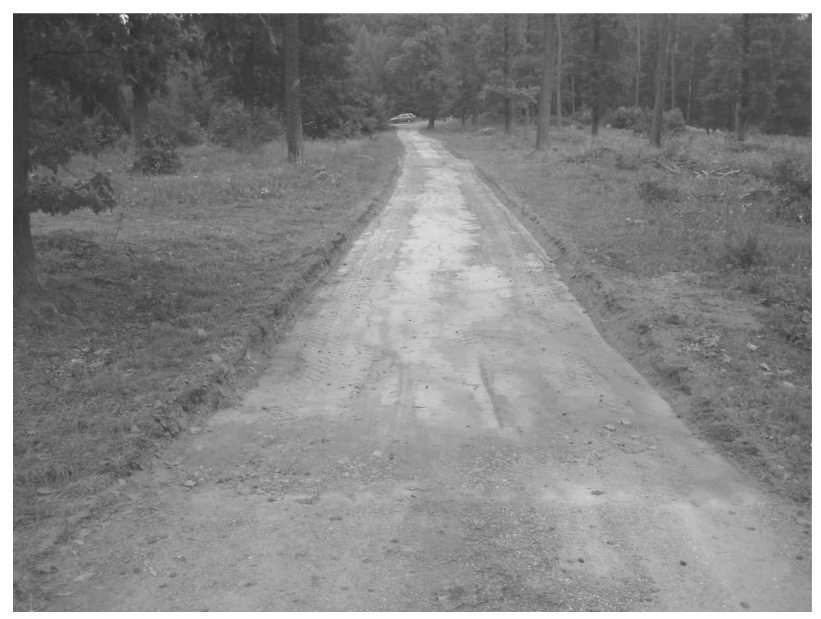

Fig. 1 Removed original subgrade (seen at the front of the picture) and preparation of new subgrade for new surfacing

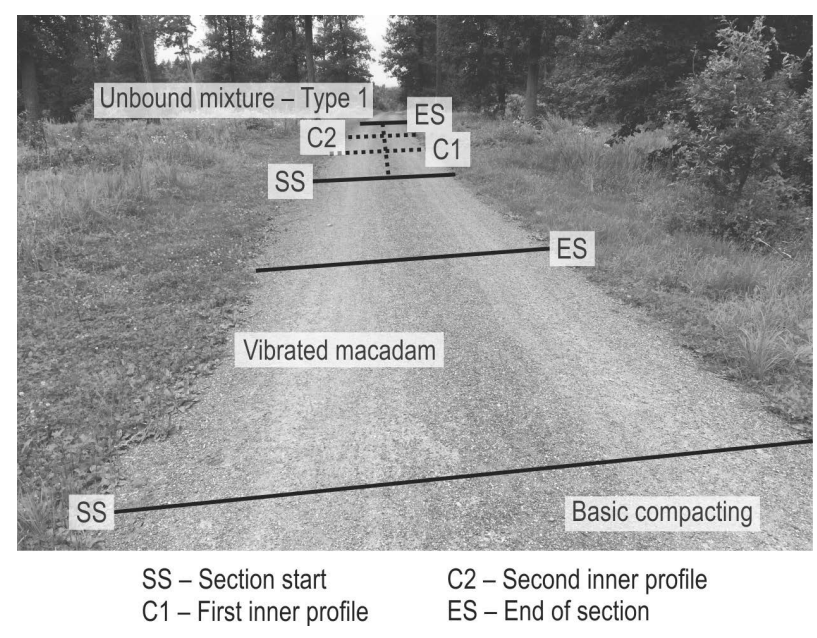

Fig. 2 Illustration of the test sections with individual construction versions

tions $0 / 12$ and $32 / 80 \mathrm{~mm}$, mixture ratio $1: 2$ ) with no added water, in contrast to traditional technology, according to ČSN 73 6126-1 (2004), compacted with a vibrating roller to a final thickness of $200 \mathrm{~mm}$. The second section was constructed using vibrated macadam technology according to ČSN 73 6126-2 (2006): crushed recycled asphalt filler fraction $0 / 12$ was vibrated into the skeleton of coarse crushed recycled asphalt aggregate fraction 32/80. (Skeleton fraction $32 / 80 \mathrm{~mm}$, $170 \mathrm{~mm}$ thick, fill material fraction $0 / 12 \mathrm{~mm}, 80 \mathrm{~mm}$ thick, compacted with a vibrating roller to a final thickness of $200 \mathrm{~mm}$ ). In the third section, half of the thickness of the original subgrade reinforcement was removed and a layer of recycled asphalt fraction $0 / 12$ was applied. This layer was then compacted with a vibrating roller to a final thickness of $100 \mathrm{~mm}$ (Fig. 2).

Immediately after their construction, the new road sections were again subjected to a static load test with the following results: unbound mixture (Edef2 98.4 MPa with Edef2/Edef1 ratio 1.77), vibrated macadam (Edef2 - 91.8 MPa with Edef2/Edef1 ratio 1.98 ) and basic compacting (Edef2 - 70.0 MPa with Edef2/Edef1 ratio 1.79).

\subsection{Static Plate Load Bearing Test with ECM - Static}

The test is used to indirectly determine the deformation moduli of unbound constructions layers. Measurement of deformation modulus (Edef2) of roads is described in ČSN 721006 (2015). The standard quantity of a road bearing capacity is the deformation modulus of the second loading cycle (Edef2), presented in $\mathrm{MPa}$. The value required by standards to determine the compaction ratio was determined as the ratio of 


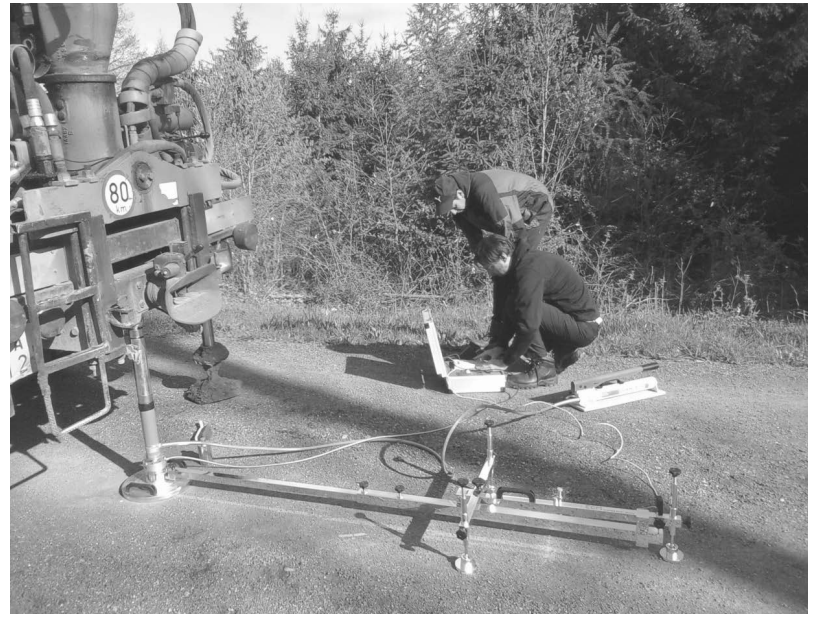

Fig. 3 Static plate load bearing test performed with the ECM Static device

the deformation moduli from the second and the first loading cycle (Edef2/Edef1). According to ČSN 73 6126-1 (2006), the ratio (Edef2/Edef1) must not exceed 2.5. If Edef1 reaches $60 \%$ of Edef2, higher Edef2/Edef1 value ratios are permitted. Relevant standards, Technical conditions and Rural Roads Catalogue of Pavements and Operational Reinforcements define the minimum and recommended values of the deformation modulus of the second loading cycle (Edef2) for the individual construction layers. Interpretation of the load bearing test is shown in a ČSN Static plate load test of soils and pavement subgrades 736190 (1980), according to which the test can only be performed when the surface is dry.

Measurements were performed with the ECM (Electronic Control \& Measurement) - Static, which is a portable, semi-automatic, geotechnical device equipped with a hydraulic loading system (a piston, a hand pump and a hose with quick coupling) with a circular loading plate of $0.3 \mathrm{~m}$ in diameter and a measuring beam with a track sensor. The whole device is connected to an electronic unit and an assessment unit. The loading plate was installed in the place where the vehicle tyres form the loading. The ECM - Static measuring device is shown in Fig. 3.

\subsection{Tacheometric Measurement of Test Sections}

In each of the test sections, four cross profiles were marked out (SS - starting section, $\mathrm{C} 1$ - first inner profile, C2 - second inner profile, ES - end section) as shown in Fig. 4 and stabilized with survey markers. To ensure correct results of the tacheometric measurements, only the two inner cross profiles ( $\mathrm{C} 1$ and $\mathrm{C} 2$ ) of each section were measured at monthly intervals.
Geodetic measurements of the control points for alignment of the tacheometric measurements with the S-JTSK coordinate system and with the Baltic Vertical Datum - After Adjustment was carried out with the Topcon Hiper Pro GNSS receiver using carrier phase measurement and real time kinematics correction from the Czech network of GNSS permanent stations (CZEPOS). Only fixed ambiguity solution was used. The expected accuracy of these GNSS measurements is better than $3 \mathrm{~cm}$ and only affects the positions of each cross profile, not the shape of the profiles. The test sections were divided into segments with $10 \mathrm{~m}$ distance from the individual cross profiles (Fig. 4). The survey markers were installed perpendicularly to the road axis at a distance of $5 \mathrm{~m}$ (approx. $0.5 \mathrm{~m}$ from the road shoulder). At each cross profile, the boundary between soil and the road surface construction layer was marked out in order to prevent distortion of the results. Deformation changes were monitored on the basis of the absolute height values.

Changes in the shape of the cross sections were detected with the Trimble M3 total station from a single stabilization point in the local system. The survey markers of the inner cross profiles were interconnected with a tape measure. In order to prevent it from sinking into the road, a ranging rod was placed directly onto the tape measure.

The profiles were then drawn in AutoCAD Civil3D, where the height of each measured point was taken in absolute height coordinates of the Baltic height system - after settlement height system.

The aim of statistical data processing was to evaluate the comparison of individual technologies based on cross-profile shape changes and relation between

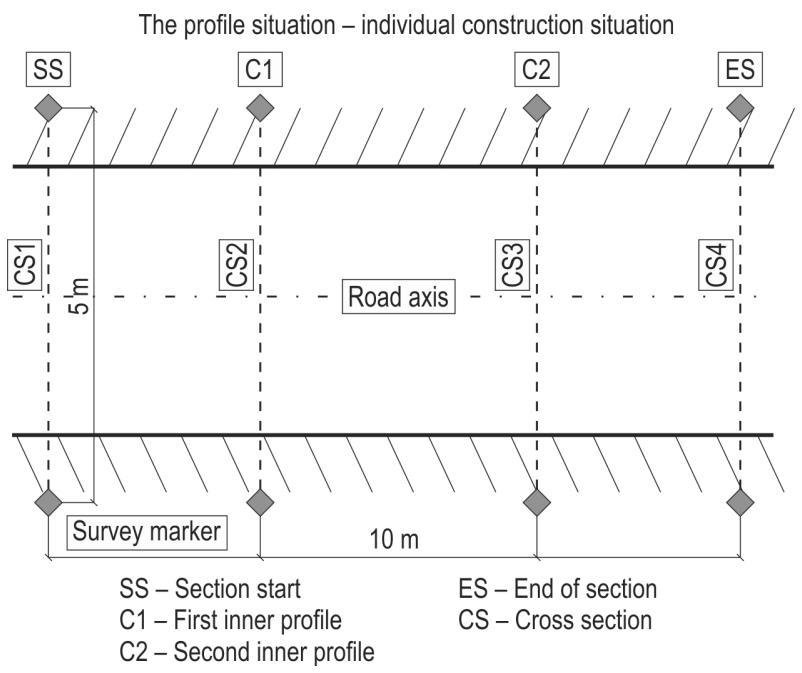

Fig. 4 A scheme of cross-profile positioning in individual test sections 
Table 1 Records of the number of passages through test sections of forest road „Babidolská»

\begin{tabular}{|c|c|c|c|c|c|c|c|c|c|c|c|}
\hline \multirow{2}{*}{\multicolumn{2}{|c|}{ Number of passages }} & \multicolumn{6}{|c|}{2016} & \multicolumn{3}{|c|}{2017} & \multirow{2}{*}{ Total } \\
\hline & & 05 & 06 & 07 & 08 & 09 & 10 & 04 & 05 & 06 & \\
\hline Number of truck passages & $n$ & 9 & 5 & 3 & 3 & 3 & 2 & 1 & 3 & 3 & 32 \\
\hline Total momentary weight of load and truck in individual months & $\mathrm{t}$ & 327.7 & 191.5 & 107.4 & 126.1 & 110.7 & 96.4 & 40.1 & 114.7 & 108.3 & 1222.7 \\
\hline Average monthly weight of load and truck & $\mathrm{t}$ & 36.4 & 38.3 & 35.8 & 42.0 & 36.9 & 48.2 & 40.1 & 38.2 & 36.1 & 38.2 \\
\hline Average monthly axle load of truck & $\mathrm{t}$ & 6.44 & 7.41 & 6.37 & 7.00 & 6.93 & 9.64 & 6.68 & 6.75 & 7.22 & 6.99 \\
\hline
\end{tabular}

Note: The total momentary weight of a fully loaded truck was calculated as the sum of the service weight declared by the truck anufacturer and the weight of the load itself. Based on the total momentary weight of the truck with load, axle load for the individual axles was determined and converted to average values in the individual months of the study

these changes and traffic load expressed by the number of passes of the design axle. In other words, we wanted to find out whether the individual technologies showed a statistically significant cross profile shape change over time, to compare the technologies with each other and determine the level of the relationship between the cross profile shape and the number of the design vehicle axle passes.

The input data included the altitudes of the road crown, measured in the cross profiles with a regular step of $0.2 \mathrm{~m}$. The measurements were repeated at the same profiles within the sections reinforced by the tested technologies at monthly intervals. The profile measurements were performed nine times. Therefore, for each point, a series of nine altitudes was obtained.

For the purpose of ANOVA, the data were adjusted so that the change of the cross profile shape was defined as the difference between the altitude values from each two consecutive measurements at the specific point. In this way, we obtained independent data for all the profiles, which allows for mutual comparison of the values measured at individual test sections, as the different altitudes of the experimental sections have been eliminated.

Statistical null hypotheses to detect deformations by tacheometric measurement in the context of the selected methods were defined as follows:

$\Rightarrow \mathrm{H}_{0}$ : shape of the cross-profile in individual technological versions does not change with time

$\Rightarrow \mathrm{H}_{0}$ : there is no difference between the tested technologies from the perspective of changes in the cross-profile shape.

\subsection{Number of Fully Loaded Logging Vehicle Passages}

Forest road Babidolská is used for seasonal timber transport by logging vehicles. Temporal changes were monitored during logging in the surrounding forest stands for a period of nine months. We have registered the volume of the hauled timber, and the number of fully loaded logging vehicle passages through the tested stretch of the road (Table 1).

Only three-axle trucks combined with either twoaxle or three-axle trailers passed through the monitored road. The results of our traffic monitoring revealed that none of the units had been overloaded and the axle weights complied with the applicable regulatory requirements and standards. Therefore, in the calculations and statistical processing, we worked with the axle weight value of $10.0 \mathrm{t}$ per single axle, which is the maximum permitted axle load according to TC 170 (2004) and Act No. 13/1997 Coll. on road communications (1997).

Between May and November 2016 and between April and June 2017, a total of 32 passages of logging vehicles were registered, out of which 16 were fiveaxle units and 16 were six-axle units. The total volume of timber transported through the test sections was $521.9 \mathrm{~m}^{3}$; together with $120 \mathrm{t}$ of gravel, the total weight of the transported load was $700.8 \mathrm{t}$. The average axle load for the whole period was $6.99 \mathrm{t}$, with an average weight of the load and the truck of $38.2 \mathrm{t}$. All of the registered values are shown in Table 1.

The relationship between the shape changes and number of design axle passages was tested by regression analysis. To verify this relationship, the least squares method was chosen - a linear regression without transformation generally expressed as $y=a+b x$ (dependent variable - shape change, independent variable - number of design axle passes). Regression diagnostics were performed by regression triplet - input data analysis, model assessment and method.

The input data for the analysis were the average monthly values of the cross-profile shape changes and the numbers of design axle passes in the respective months. As the test sections were constructed on the 
Table 2 Comparison of deformation modulus values (Edef2) measured at forest road „Babidolská» with standardized minimum values of deformation moduli (Edef2 min.) for construction layers

\begin{tabular}{|c|c|c|c|c|c|c|c|c|}
\hline \multicolumn{2}{|c|}{$\begin{array}{l}\text { Rural Roads Catalogue } \\
\text { Catalogue Sheet 6-5 (2011) }\end{array}$} & \multicolumn{7}{|c|}{$\begin{array}{l}\text { Static plate load bearing test } \\
\text { according to ČSN } 736190 \text { (1980) }\end{array}$} \\
\hline \multicolumn{2}{|c|}{ Flexible pavements - unbound running surfaces } & \multicolumn{7}{|c|}{ Forest road »Babidolská» } \\
\hline \multicolumn{2}{|c|}{$\begin{array}{c}\text { Traffic load class Vl; } \\
\text { Design damage level D 2; } \\
\text { Deformation modulus of subgrade } 30 \mathrm{MPa}\end{array}$} & \multicolumn{7}{|c|}{$\begin{array}{l}\text { Deformation modulus of the second } \\
\text { loading cycle (Edef2), MPa }\end{array}$} \\
\hline \multirow{2}{*}{$\begin{array}{l}\text { Designation - subgrade layer } \\
\text { layer thickness in mm }\end{array}$} & \multirow{2}{*}{$\begin{array}{l}\text { Minimum value of deformation modulus } \\
\text { (Edef2 min.) of construction } \\
\text { layers according to Catalogue }\end{array}$} & \multicolumn{3}{|c|}{2016} & \multicolumn{2}{|c|}{2017} & \multicolumn{2}{|c|}{$\begin{array}{l}\text { Average value of the whole } \\
\text { period of measurement }\end{array}$} \\
\hline & & 05 & 07 & 09 & 05 & 06 & (Edef2) & (Edef2)/(Edef1) \\
\hline Unbound mixture - Type 1, $200 \mathrm{~mm}$ thick & $115 \mathrm{MPa}$ & 83.7 & 81.6 & 88.8 & 91.1 & 96.8 & 88.4 & 2.04 \\
\hline Vibrated macadam, $200 \mathrm{~mm}$ thick & $110 \mathrm{MPa}$ & 83.9 & 76.4 & 67.7 & 75.5 & 71.2 & 74.9 & 1.97 \\
\hline Basic compacting, $100 \mathrm{~mm}$ thick & $100 \mathrm{MPa}$ & 73.1 & 90.2 & 103.8 & 92.1 & 90.2 & 89.9 & 1.97 \\
\hline
\end{tabular}

same forest road, they were exposed to equal traffic load. In the context of the selected method, the analysis of the input data from individual road reinforcement technologies was performed, focusing on the identification of the influential values and their classification, according to their occurrence as outliers and extreme values. Outliers were removed based on the graphs of influential points, following the Bayes' rule, as the intention is to work only with the group of data most precisely representing the selected model (Meloun and Militký 2004). Estimations of equation parameters $a, b$ for individual technological versions of road reinforcement were performed together with the respective confidence intervals, allowing the determination of their statistical significance, together with the standard deviations.

\section{Results}

\subsection{Results of Static Plate Load Bearing Test According to ČSN 721006 (1998)}

The minimum deformation moduli values (Edef2 min.) set by the Rural Roads Catalogue (2011) are: $115 \mathrm{MPa}$ for a road surface made of natural quarry aggregate with unbound mixture - Type1 technology, $110 \mathrm{MPa}$ for vibrated macadam and $100 \mathrm{MPa}$ for basic compacting.

Deformation modulus (Edef2) values determined by the static plate load bearing test for technological version III - basic compacting reached 73.1-103.8 MPa and the ratio of the deformation moduli from the sec- ond and the first loading cycle (Edef2/Edef1) was between 1.80 and 2.21. Version II - a modified vibrated macadam technology - reached the deformation modulus (Edef2) values of 67.7-83.9 MPa and the Edef2/ Edef1 ratio was between 1.93 and 2.06. In version I - a modification of the unbound mixture-Type1 technology - Edef2 reached 81.6-96.8 MPa with the Edef2/ Edef1 ratio between 1.69 and 2.35.

The best results were achieved with version III basic compacting, where a $100 \mathrm{~mm}$ layer of recycled asphalt filler fraction $0 / 12$ was vibrated into the original basic compacting of coarse crushed aggregate fraction $32 / 63 \mathrm{~mm}$ and the average deformation modulus value reached $88.9 \mathrm{MPa}$ with an average Edef2/Edef1 ratio of 1.94. Comparable results were also obtained with modified unbound mixture technology - Type1, where the coarse skeleton of recycled asphalt fraction 32/80 was mixed with a filler fraction $0 / 12$, with an average deformation modulus value of $88.4 \mathrm{MPa}$ and an average Edef2/Edef1 ratio of 2.04. The worst results were observed in the vibrated macadam technology, where the recycled asphalt filler fraction 0/12 was vibrated into the skeleton of the same material fraction 32/80, with an average deformation modulus value of $74.9 \mathrm{MPa}$ and an average Edef2/Edef ratio of 1.97. Detailed results of the deformation modulus measurements (Edef2) in the individual months are shown in Table 2.

\subsection{Deformation Characteristics from Tacheomet- ric Measurements of Test Sections}

Furthermore, the first null hypothesis on the extent of the shape change over time was tested (ANOVA 
with interactions). This hypothesis was rejected. Although the differences in the shape changes were statistically significant only in the first months of the measurements, after the first winter period they became statistically insignificant (Fig. 5). Specific differences were tested by multiple comparison tests (Fisher, Tukey).

The graph in Fig. 5 shows that in the first months after construction, the road did not show signs of gradual rutting, rather it showed partial fluctuations or corrugation in the first year after construction, mainly in the sections reinforced with the basic compaction and vibrated macadam technologies. However, the changes did not exceed $1 \mathrm{~cm}$ in height and are common for all technologies after the first postconstruction winter due to gradual consolidation; as regards the changes of shape between the individual measurements, no difference between the tested technologies was observed.

Analysis of variance (one-way ANOVA) was used to test the second null hypothesis that there is no difference between the technological versions regarding the shape of their cross profile. This hypothesis was confirmed, and we can state that the shape changes in the experimental sections constructed with basic compacting, vibrated macadam and unbound mixture Type1 technologies are statistically insignificant. The smallest differences were observed in the version using unbound mixtures (Fig. 6).

\subsection{Number of Passages of Fully Loaded Logging Vehicles}

Passage records revealed that none of the trucks had been overloaded and the axle loads fulfilled the requirements of the applicable regulations and standards. The relationship between the number of the design axle passages and the changes of the road cross-profile shape was analyzed with the aid of linear regression in a general form $y=a+b x$. Exploratory data analysis included data cleanup and identifying outliers and extremes. The dependent variable y represents shape changes and the independent variable $x$ represents the number of the design axle passages. The results of estimating equation parameters $a, b$ for particular technologies are summarized in Table 3.

Based on Silen's rule (Meloun and Militky 2004), the estimates of the equation parameters were found statistically insignificant (triple standard deviation exceeds the value of the parameter). The parameter estimations were tested by Student's $t$-test (all $p$-values $>0.05$ ) and confidence limit test. Confidence limits contain the value 0 in all cases. The results of both tests denote the insignificancy of the parameter estimates.

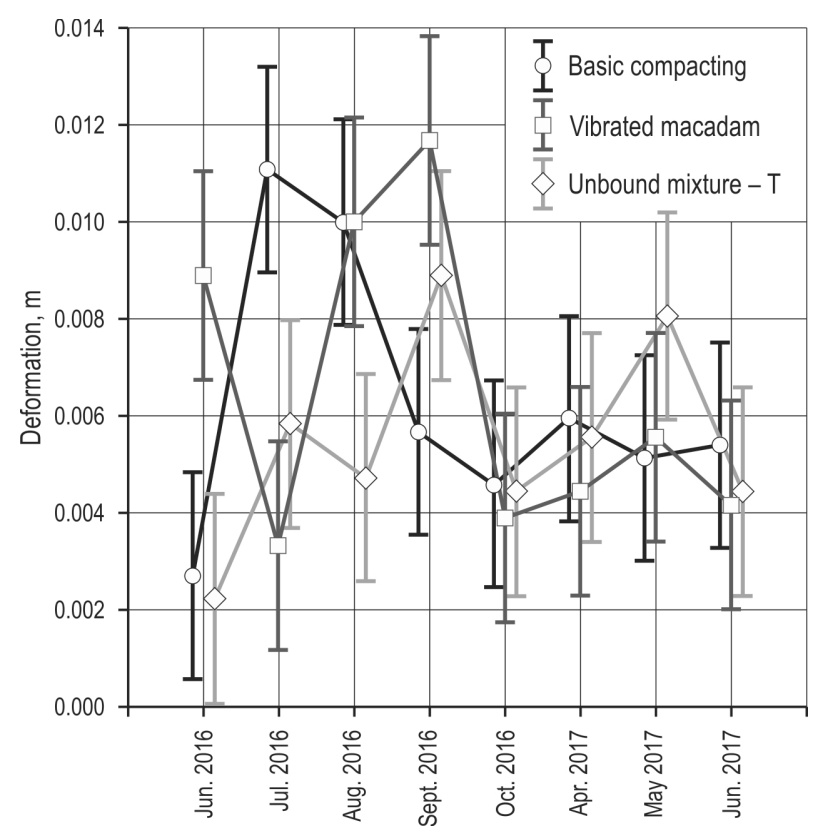

Fig. 5 Shape changes of individual technologies with time (ANOVA)

The insignificancy of the models for all technologies was affirmed by the results of Fisher-Snedecor test. Scott multicolinearity test, Cook-Weisberg test of heteroscedasticity, Jarque-Berra test of normality, Wald test of autocorrelation and Durbin-Watson autocorrelation test were used as regression diagnostics (tests

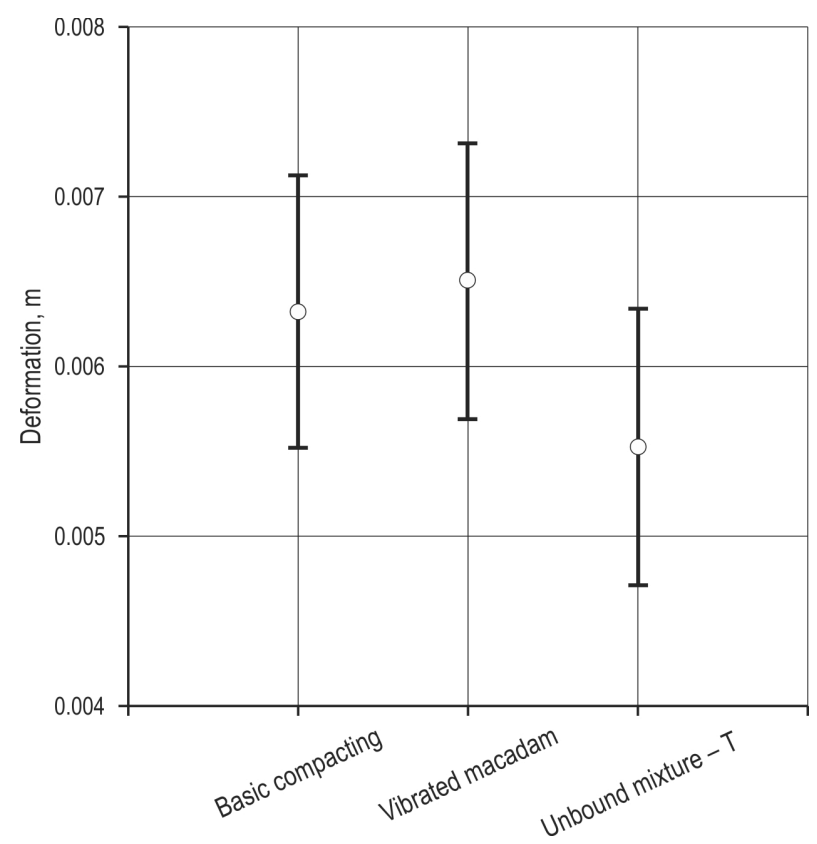

Fig. 6 Comparison of technologies from the viewpoint of the total average value of the surface shape change over the monitored period (ANOVA) 
Table 3 Estimation of parameters (SD - standard deviation, CL - confidence limits)

\begin{tabular}{|c|c|c|c|c|c|c|c|}
\hline Technology & Parameter & Estimation & SD & $p$-value & Lower CL & Upper CL & Result \\
\hline \multirow{2}{*}{ Basic compacting } & $a$ & 0.00433 & 0.0040 & 0.33 & -0.0061 & 0.0147 & insignificant \\
\cline { 2 - 8 } & $b$ & 0.00025 & 0.0004 & 0.55 & -0.0007 & 0.0013 & insignificant \\
\hline \multirow{3}{*}{ Vibrated macadam } & $a$ & 0.00112 & 0.0025 & 0.67 & -0.0052 & 0.0074 & insignificant \\
\cline { 2 - 8 } & $b$ & 0.00041 & 0.0002 & 0.10 & -0.0001 & 0.0009 & insignificant \\
\hline \multirow{2}{*}{ Unbound mixture - Type 1 } & $a$ & 0.00545 & 0.0032 & 0.14 & -0.0027 & 0.0136 & insignificant \\
\cline { 2 - 8 } & $b$ & 0.00005 & 0.0003 & 0.86 & -0.0007 & 0.0008 & insignificant \\
\hline
\end{tabular}

of residuals) to support the mentioned statements correctness verification of the models. Besides, the models show low determination coefficient values and therefore it is not possible to conclude that there is a statistically significant directly proportional relationship between the number of design axle passages and the changes of the road cross profile shape (Fig. 7).

\section{Discussion}

The technical conditions of the Rural Roads Catalogue, issued by the Ministry of Agriculture of the Czech Republic (2011), which is also the technical documentation for the formation of forest road surfaces, sheet Flexible pavements - unbound running surfaces, state that the minimum values of the deformation modulus from quarry aggregate are $115 \mathrm{MPa}$ for unbound mixture - Type 1, $110 \mathrm{MPa}$ for vibrated macadam, and $100 \mathrm{MPa}$ for basic compacting. Within the present study, these values were not reached. The average values of the nine measurements were $88.4 \mathrm{MPa}$ for the unbound mixture technology, 74.9 MPa for the vibrated macadam technology and $89.9 \mathrm{MPa}$ for basic compacting. In spite of the fact that the deformation characteristics of the deformation modulus reached only $62.4-89.9 \%$ of the values required by the standard for common natural aggregates, statistical processing of the tacheometric measurements revealed statistically significant changes in the cross-profile shape, the test sections did not show any signs of rutting. Transversal corrugation of the road surface was only observed in the first months after construction and was followed by gradual consolidation and stabilization of the shape.

A negative phenomenon - a gradual increase in the deformation moduli ratio - was observed in all tested construction versions (with only some minor deviations). This means that, just like in roads reinforced with traditional crushed aggregate, regular mainte- nance in the form of compaction with a vibrating roller is necessary.

The compaction ratio expressed as the deformation moduli ratio (Edef2/Edef1) was below the decisive limit of 2.5 in all construction versions. These values can be declared as complying with the requirements for the common construction layers of reinforcement, according to ČSN 73 6126-1 (2006). Basic compacting showed fluctuating results during the whole measurement period. This can be explained by the technological solution itself, in which the original skeleton of natural crushed aggregate fraction 32/63 thickness of 100 was left in this road formation active zone. However, the deformation characteristics of the deformation modulus are virtually the same as in the recycled asphalt unbound mixture, which indicates that this technology is sufficient in roads previously reinforced with natural aggregate.

Based on these findings, recycled asphalt can be used without limitations in unbound constructional layers for seasonal forest haul road running surfaces. The price of recycled asphalt was $1.3 \mathrm{EUR} / \mathrm{t}$, while the price of stone from a natural quarry was approximately $8.3 \mathrm{EUR} / \mathrm{t}$. From an economic point of view, the material transfer distance is the most determining. Recycled asphalt is usually found in recycling centres in near large cities. The price difference and the amount of recycled material then represent the economic limit for the material transfer distance. Statistical processing of the measured data did not reveal significant differences in the road surface value changes, i.e., there is no difference between the three technologies tested. A regression between the number of vehicle passes and the deformation moduli measured at the sections reinforced with the individual technologies was not confirmed; therefore, we can conclude that all three construction versions had sufficient dimensions for the required traffic load.

Various authors (Kaakkurivaara et al. 2016, Behnood et al. 2015, Zhang end Gao 2015, Vestin et al. 


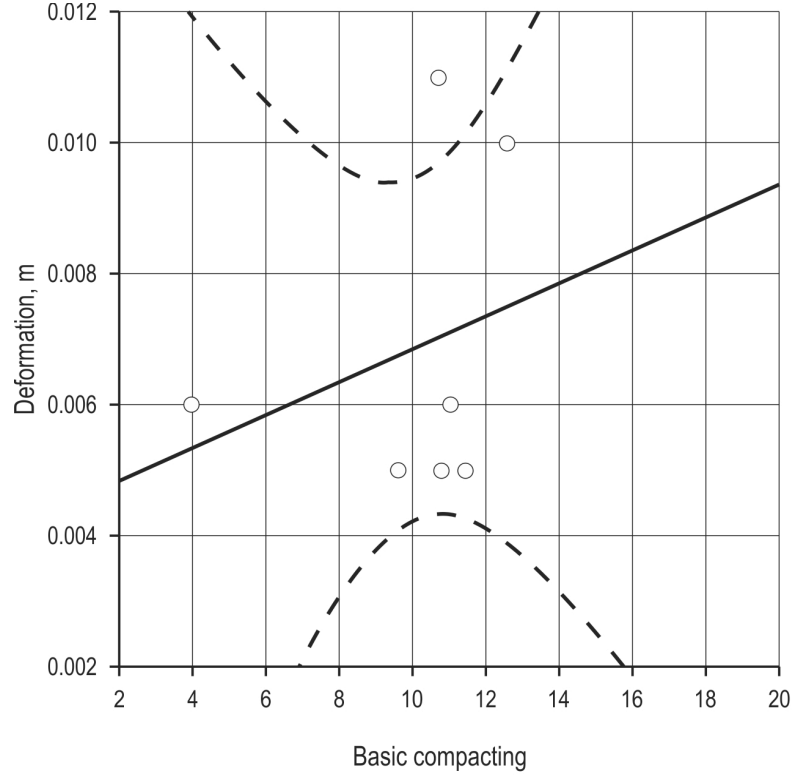

Number of design axle passages

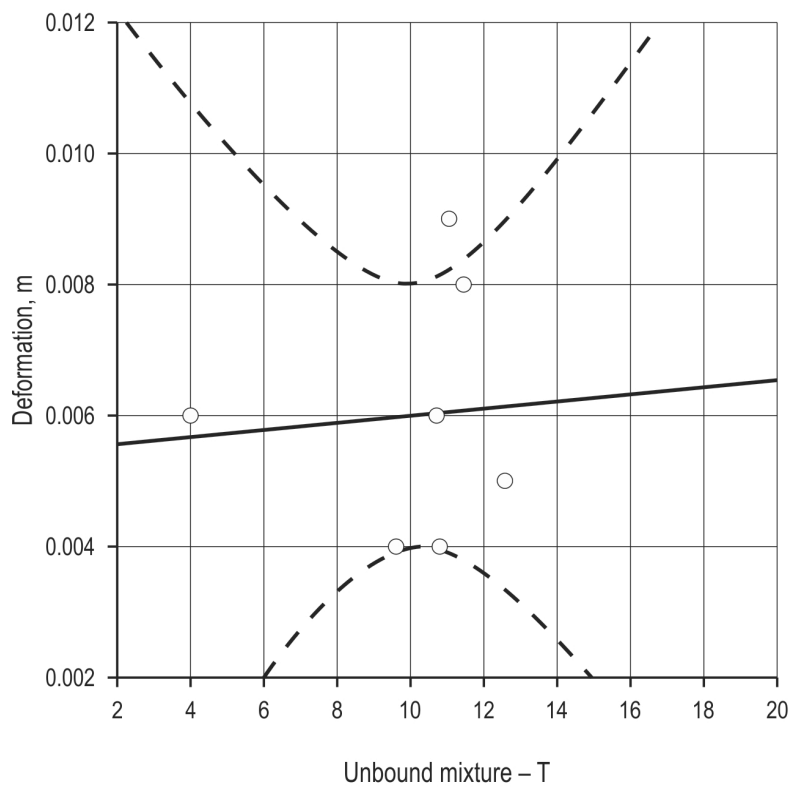

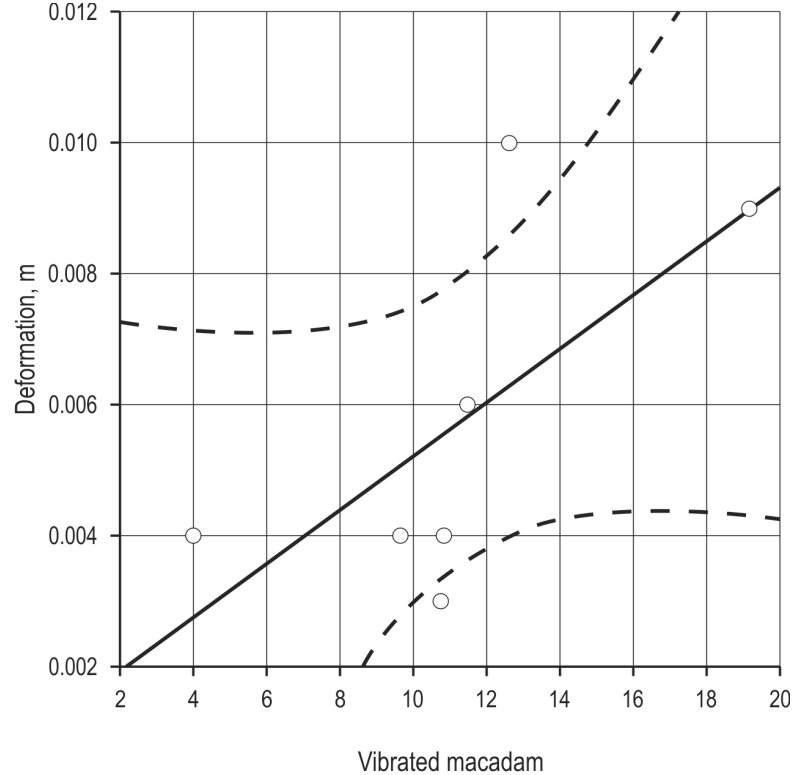

Number of design axle passages

Basic compacting: $y=0.0043+0.0003^{*} x ; R^{2}=0.077$ Vibrated macadam: $y=0.0011+0.0004^{*} x: R^{2}=0.444$ Unbound mixture - Type 1: $y=0.0054+5.4917 \mathrm{E}-5^{*} x ; R^{2}=0.007$

Number of design axle passages

Fig. 7 Relationship between the shape changes and the number of design axle passages (regression analysis)

2012) adopted different approaches to the use of construction and demolition waste in transport engineering. The authors tried to achieve the best chemical, physical and mechanical properties of recycled mixtures using two or more types of waste at the same time. Unlike them, this study focuses on monitoring the deformation characteristics of recycled asphalt used with cold-mix technology. The forest road is thus paved with only a single type of waste.
Kaakkurivaara et al. (2016) discussed the issue of forest road network reinforcement with fly ash and its mixtures using three methodologies: dynamic cone penetrometer, light falling weight deflectometer, and falling weight deflectometer. In total, four types of road reinforcement for an existing road network were investigated in their study for three years. The first version was a layer consisting of a fly ash mixture and quarry aggregate in the ratio of 1:2, $140 \mathrm{~mm}$ thick. The second 
technology was made up of a mixture ratio of 1:1 and a thickness of $200 \mathrm{~mm}$. The third and the fourth versions of reinforcement were only fly ash of various layer thicknesses (250 and $500 \mathrm{~mm}$ ). All the technologies were complemented with a wearing course of quarry aggregate, $0 / 32 \mathrm{~mm}$ fraction, $100 \mathrm{~mm}$ thick. The sections formed from a mixture of fly ash and quarry aggregate achieved higher bearing capacity. Despite the different measurement methodology, the same positive phenomenon was observed in all test sections: the deformation modulus of the test sections increased with the actual use of the forest road. Schlaghamersky and Barfod (1993) and Bohrn end Stampfer (2014) also observed an increasing bearing capacity in their sections, consisting of a mixture of recycled materials and ash. Similar changes with time have been observed in our measurements. In addition, Schlaghamersky (2005) measured deformation characteristics using the Harrell penetration meter immediately after the forest road reconstruction and related his results to the number of passages by logging trucks. He determined that after 20 logging trucks passages, deformations of the road surface occured at the places of pressure by tyres. The rutting was deeper, and the mixture was less stable in the version with a thicker structural layer $(>200 \mathrm{~mm})$.

\section{Conclusion}

Technologies based on the use of recycled material hold enormous potential and therefore deserve adequate attention. The technological procedure ensuring good material quality depends on correctly collecting the construction waste, subsequent crushing, sorting, and separating unsuitable material during the individual phases of processing. Activities associated with forest haul roads and their construction, reconstruction or repair works offer a wide scale of possible secondary recycled asphalt uses. They help to reduce the exploitation of the natural non-renewable aggregate resources and at the same time they lower the volume of the waste produced during road repairs and reconstruction. From the aspect of implementation, the proposed technological solution is simple, effective and nature-friendly, suitable also for small owners and administrators of roads. Besides, the prices of recycled material are often lower than the prices of quarry aggregates. However, it is always necessary to analyse the advantages of the technology used in terms of economic effects, i.e. compare the transportation distance and the amount of material. Obviously, it is necessary to adhere to the applicable laws and regulations in force in the country. This study has verified the possible use of technology for forest engineering and proved that the load bearing capacity will be sufficient if the construction layers are suitably designed. New complex utilization of recycled material and its mixtures to reinforce forest road network could be the subject of further research. Regrettably, a general problem is poor knowledge on the possible use of recycled material and waste management.

\section{Acknowledgments}

The project received funding from the Internal Grant Agency, Mendel University in Brno, No. LDF_ PSV_2016016.

\section{References}

Agrella, F., Barbudo, A., Ramírez, A., Ayuso, J., Carvajal, D. M., 2012: Construction of road sections using mixed recycled aggregates treated with cement in Malaga, Spain. Resources, Conservation and Recycling 58: 98-106. https://doi. org/10.1016/j.resconrec.2011.11.003

Behnood, A., Gharehveran, M.M., Asl, F.G., Ameri, M., 2015: Effects of copper slag and recycled concrete aggregate on properties of CIR mixes with bitumen emulsion, rice husk ash, Portland cement and fly ash. Construction and Building Materials 96: 172-180. https://doi.org/10.1016/j.conbuildmat.2015.08.021

Bohrn, G., Stampfer, K., 2014: Untreated Wood Ash as a Structural Stabilizing Material in Forest Roads. Croatian Journal of Forest Engineering 35(1): 81-89.

BS 1377, 1990: Part 4: Methods of test for soils for civil engineering purposes. Compaction-related tests.

Cibonau, V., Alexandru, V., Saceanu, S.C., 2012: Degradation forms of forest gravel road roadways under heavy vehicles used in timber transport. Bulletin of the Transilvania University of Brasov 5(54 Part 1): 37-42.

Cimpan, C., Maul, A., Wenzel, H., Pretz, T., 2016: Technoeconomic assessment of central sorting at material recovery facilities - the case of lightweight packaging waste. Journal of Cleaner Production 112: 4387-4397. https://doi. org/10.1016/j.jclepro.2015.09.011

Český normalizační institut, 1980: ČSN 736190 Statická zatěžovací zkouška podloží a podkladních vrstev vozovky, Praha.

Český normalizační institut, 1995: ČSN 736114 Vozovky pozemních komunikací, Základní ustanovení pro navrhování, Praha.

Český normalizační institut, 1998: ČSN 721006 Kontrola zhutnění zemin sypanin. Praha, $44 \mathrm{p}$.

Český normalizační institut, 2006: ČSN 73 6126-1 Stavba vozovek - nestmelené vrstvy - Část 1: Provádění a kontrola shody. Praha, 12 p.

Český normalizační institut, 2006: ČSN 73 6126-2 Stavba vozovek - nestmelené vrstvy - Část 2: Vrstva z vibrovaného štěrku, Praha. 
Český normalizační institut, 2011: ČSN ČSN EN 13285 (73 6155). Nestmelené směsi - Specifikace (Unbound mixtures - Specification), Praha.

Český normalizační institut, 2016: ČSN 73 6108. Lesní cestní sít. Forest Road Network. Praha, 44 p.

De Beir, J., Fodha, M., Magris, F., 2010: Life cycle of products and cycles. Macroeconomic Dynamics 14(3): 212-230.

Decree no. 294/2005 Coll., on the conditions of depositing waste in land fills and its use on the surface of the ground.

Decree no. 383/2001 Coll., on details of waste management.

DIN 18134 Baugrund, 1990: Versuche und Versuchsgerate; Plattendruckversuch.

Edil, T., Benson, H., 2007: Demonstration of ash utilization in low volume roads. Research report 2007-12. Minnesota Department of Transportation, $233 \mathrm{p}$.

Garach, L., López, M., Agrela, F., Ordóñez, J., Alegre, J., Moya, J., 2015: Improvement of bearing capacity in recycled aggregates suitable for use as unbound road sub-base. Materials 8(12): 8804-8816. https://doi.org/10.3390/ma8125493

Gruber, J., 2003: Po cestách - necestách. Zpravodaj SPŠ strojnické v Plzni. Plzeň: 2 p.

Hirt, R., 1998: Use of recycled aggregates in construction of forest and rural roads. Schweizerische Zeitschrift fur Forstwesen 149(11): 901-908.

Hoppe, E.J., Lane, S.D., Fitch, M.G., 2015: Feasibility of Reclaimed Asphalt Pavement (RAP) Use As Road Base and Subbase Material. Virginia Center for Transportation Innovation and Reasearch. Final Report VCTIR 15-R6. Charlottesville, Virginia, $42 \mathrm{p}$.

Hrůza, P., Pelikán, P., Blahuta, J., Nedorost, J., Patočka, Z., 2016: A Structural Reinforcement Layer with Woodchips Used on Forest Roads. Nova Mehanizacija Šumarstva 36(1): 29-39.

Jagannadha, R.K., 2015: Suitability of recycled aggregate in fibre reinforced high strength concrete for sustainability. Journal of Structural Engineering 42: 264-272.

Kaakkurivaara, T., Kolisoja, P., Uusitalo, J., Vuorimies, N., 2016: Fly Ash in Forest Road Rehabilitaion. Croatian Journal of Forest Engineering 37(1): 119-130.

Kang, D.H., Gupta, S.C., Bloom, P.R., Raivoson, A.Z., Roberson, R., Siekmeier, J., 2011: Recycled materials as substitutes for virgin aggregates in road construction: I. Hydraulic and mechanical characteristics. Soil Science Society of America Journal 75(4): 1265-1275. https://doi.org/10.2136/sssaj2010.0295

Lahtinen, P., 2001: Fly ash mixtures as flexible structural materials for low-volume roads. Finnra Reports 70/2001. Finnish Road Administration, 95 p.

Leite, F.D.C., Motta, R.D.S., Vasconcelos, K.L., Bernucci, L., 2011: Laboratory evaluation of recycled construction and demolition waste for pavements. Constr. Build. Mater. 25(6): 2972-2979. https://doi.org/10.1016/j.conbuildmat.2010.11.105 Liu, S., Shukla, A., Nandra, T., 2017: Technological, environmental and economic aspects of Asphalt recycling for road construction. Renewable and Sustainable Energy Reviews 75: 879-893. https://doi.org/10.1016/j.rser.2016.10.080

Makovník, Š., Jurík, L., Beneš, J., Kompan, F., 1973: Inžinierske stavby lesnícke. Príroda, Bratislava, 710 p.

Meloun, M., Militký, J., 2004: Statistická analýza experimentálních dat. Vyd. 2., upr. a rozš. Praha: Academia, 954 p.

MZE, 2010: Zpráva o stavu lesa a lesního hospodářství České republiky v roce 2009 (Report on the Status of Forests of the Czech Republic in 2009). Praha. Ministerstvo zemědělství, $116 \mathrm{p}$.

Navrhování vozovek pozemních komunikací (Designing of roadways), 2011: Technické Podmínky 170 - změna č. 2: Katalog Vozovek Polních Cest. (Technical Conditions 170 amendment no. 2: Rural Roads Catalogue): Vydaný Ministerstvem zemědělství - Ústředním pozemkovým úřadem pod č. j. 43385/2011 ze dne 1.3.2011, 62 p.

Navrhování vozovek pozemních komunikací (Designing of roadways), 2004: Technické Podmínky 170 (Technical Conditions 170): schváleno MD ČR OPK pod č. j. 517/04-120-RS/1 ze dne 23. 11. 2004 s účinností od 1. prosince 2004. Praha: Ministerstvo dopravy České republiky, 100 p.

Navrhování vozovek pozemních komunikací (Designing of roadways), 2010: Dodatek Technické Podmínky 170 (Supplement technical Conditions 170): schváleno MD ČR OPK pod č. j. 682/10-910-IPK/1 ze dne 12. 8. 2010 s účinností od 1. záŕí 2010. Praha: Ministerstvo dopravy České republiky, 37 p.

Navrhování vozovek pozemních komunikací (Designing of roadways), 2011: Technické Podmínky 210: Užití recyklovaných stavebních demoličních materiálů do pozemních komunikací (Supplement technical Conditions 210: Use of recycled building demolition materials on roads). Schváleno MD - OSI č. j.1118/10-910-IPK/1 ze dne 15.12. 2010 s účinností od 1.1. 2011. Vysoké učení technické v Brně, Fakulta stavební, 23 p.

Rao, M.C., Bhattacharyya, S.K., Barai, S.V., 2011: Influence of field recycled coarse aggregate on properties of concrete. Materials and Structures 44(1): 205-220.

Saride, S., Avirneni, D., Javvadi, S.C.P., 2016: Utilization of Reclaimed Asphalt Pavements in Indian Low-Volume Roads. Journal of Materials in Civil Engineering 28(2): 04015107.

Schlaghamersky, A., Barfod, H.H., 1993: Track road building and recycling material for road consolidation. AFZ, Allgemeine Forst Zeitschrift. 49(24): 1332-1344.

Schlaghamersky, A., 2005: Simple reinforcement of forest roads using recycled construction material. Mehanizacija šumarstva 2001-2004: Special Issue of the Journal 26 (2): 107-111.

Tabsh, S.W., Abdelfatah, A.S., 2009: Influence of recycled concrete aggregates on strength properties of concrete. Constr. Build. Mater. 23(2): 1163-1167. https://doi.org/10.1016/j.conbuildmat.2008.06.007

Trcinski, G., Sieniawski, W., Moskalik, T., 2013: Effects of timber loads on gross vehicle weight. Folia Forestalia Polonica, Series A, Forestry 55(4): 159-167. https://doi. org/10.2478/ffp-2013-0017 
Vestin, J., Arm, M., Nordmark, D., Lagerkvist, A., Hallgren, P., Lind, B., 2012: Fly ash as a road construction material. Conference: Int Conf on Environmental and technical implications of construction with alternative materials. WASCON, Gothenburg, Sweden, 8 p.

Wen, H., Wu, M., Wang, J., 2013: Development of rutting model for unbound aggregates containing recycled asphalt pavement. Geotechnical Testing Journal 36(2): 236-241. https://doi.org/10.1520/GTJ20120102

Wu, M., Wen, H., Balasingam, M., Manahiloh, K., 2012: Influence of recycled asphalt pavement content on air void distribution, permeability, and modulus of base layer. Transportation Research Record 2267(1): 65-71. https://doi. org/10.3141/2267-08

Xuan, D.X, Houben, L.J.M., Molenaar, A.A.A., 2012: Mechanical properties of cement-treated aggregate material $-\mathrm{A}$ re- view. Materials \& Design 33: 496-502. https://doi. org/10.1016/j.matdes.2011.04.055

Zákon č. 13/1997 Sb., o pozemních komunikacích (Act no. 13/1997 Coll. on road communications).

Zákon č. 183/2006 Sb. o územním plánování a stavebním řádu (stavební zákon) (Act no. 183/2006 Coll.,on town and country planning and building code (Building Act)).

Zhang, Y.C., Gao, L.L., 2015: Experimental Research on Pavement Performance of Recycled Tire Rubber Powder Modified Concrete. CICTP 2015 - Efficient, Safe, and Green Multimodal Transportation - Proceedings of the $15^{\text {th }}$ COTA International Conference of Transportation Professionals, 911-918 p.

ZTVE StB 94, 1997: Zusatzchlische Technische Vertragsbedingungen und Richtlinien für Erdarbeiten im Strassenbau.

(C) 2019 by the authors. Submitted for possible open access publication under the terms and conditions of the Creative Commons Attribution (CC BY) license (http://creativecommons.org/licenses/by/4.0/).

Received: August 24, 2018

Accepted: April 25, 2019
Authors' addresses:

Assoc. prof. Petr Hrůza, PhD *

e-mail: petr.hruza@mendelu.cz

Assist. prof. Petr Pelikán, PhD

e-mail: petr.pelikan@mendelu.cz

Ing. Jaroslav Blahuta

e-mail:xblahuta@mendelu.cz

Ing. Lucie Olišarová

e-mail: xolisaro@node.mendelu.cz

Department of Landscape Management

Faculty of Forestry and Wood Technology

Mendel University in Brno

Zemědělská 3

613 00, Brno

THE CZECH REPUBLIC

Assist. prof. Tomáš Mikita, PhD

e-mail: tomas.mikita@mendelu.cz

Assist. prof. Zdeněk Patočka, PhD

e-mail: zdenek.patocka@mendelu.cz

Ing. Jiř́i Nedorost

e-mail: jiri@nedorost.cz

Department of Forest Management and Applied

Geoinformatic

Faculty of Forestry and Wood Technology

Mendel University in Brno

Zemědělská 3

613 00, Brno

THE CZECH REPUBLIC

* Corresponding author 